\title{
Varietal Preference of Mango fruit Borer Autocharis albizonalis Hampson in Regard to the Phenol Content of the Fruit
}

\author{
Mainak Bhattacharyya*
}

Dept. of Agricultural Entomology, Bidhan Chandra Krishi Viswavidyalaya, Mohanpur, Nadia, West Bengal (741252), India

\author{
Corresponding Author \\ Mainak Bhattacharyya \\ e-mail: mainakbckv24@gmail.com
}

\author{
Article History \\ Article ID: 3 C0111 \\ Received in 09 ${ }^{\text {th }}$ September, 2017 \\ Received in revised form $14^{\text {th }}$ December, 2017 \\ Accepted in final form $28^{\text {th }}$ January, 2018
}

\begin{abstract}
Varietal preference of mango fruit borer (Autocharis albizonalis Hampson ) was determined in regard to the Phenol content of the fruit in Department of Plant Physiology, Bidhan Chandra Krishi Viswavidyalaya, Mohanpur, Nadia, West Bengal. Total estimation of Phenol was carried out with the Folin-Ciocalteau reagent. It was determined that pulp phenol level of the fruits of the mango cultivars ranged from $5.707 \mathrm{mg} \mathrm{kg}^{-1}$ to $23.57 \mathrm{mg} \mathrm{kg}^{-1}$ at marble stage, $2.537 \mathrm{mg} \mathrm{kg}^{-1}$ to $13.493 \mathrm{mg} \mathrm{kg}^{-1}$ at egg stage and from $1.023 \mathrm{mg} \mathrm{kg}^{-1}$ to $11.023 \mathrm{mg} \mathrm{kg}^{-1}$ at maturity stage of the fruit. The variations in pulp phenol level of mango cultivars under study were significant at all three stages indicating inherent differences in this respect among the cultivars. Himasagar at marble stage had phenol content $21.060 \mathrm{mg} \mathrm{kg}^{-1}$ in the pulp. Gradually, the phenol content declined to $11.023 \mathrm{mg} \mathrm{kg}^{-1}$ in the pulp at maturity when infestation of the pest on the variety reached its highest. The correlation study of fruit borer infestation revealed that its infestation was strongly associated with pulp phenol level of fruit maturity $(r=0.78)$ and egg stage $(r=0.73)$ where as it did not have any association with pulp phenol level at marble stage $(r=0.44)$.
\end{abstract}

Keywords: Egg stage, Folin-ciocalteau reagent, himsagar, mango fruit borer, phenol

\section{Introduction}

The study on the incidence pattern of mango fruit borer (Autocharis albizonalis Hampson) was carried out along with the different aspects of infestation and their varietal preference. The fruit borer infestation occurred from pea to marble sized stage of the fruit and continued till maturity stage. The first pest brood was seen in the first fortnight of March and continued till June. Study of the incidence pattern and the varietal preference of mango fruit borer during 2008 to 2009 and 2009 to 2010 showed that in the year 2009 to 2010 the infestation of the pest started from the first week of April when fruits were in the pea to marble size, infestation reached maximum during $2^{\text {nd }}$ fortnight of April (i.e. $2.29 \%$ ) when temperature, relative humidity and rainfall regime were in the range 29.04 and $42.48{ }^{\circ} \mathrm{C}$. The relative humidity range $14 \& 100 \%$ and rainfall regime $0 \mathrm{~mm}$ respectively. Later the population was found to decline. Lowest infestation was found at the end of May when temperature, relative humidity and rainfall were in the range of $25.3-36.2^{\circ} \mathrm{C}$, the humidity ranged between $63 \& 97 \%$ and rainfall being $5.7 \mathrm{~mm}$ respectively.

In the next year early appearance of the pest was noticed at the pea stage of the fruit. Peak damage (i.e. 3.81\%) was observed during last week of March in the year 2010 when temperature, relative humidity and rainfall regime were in the range of 36.6 and $16.9{ }^{\circ} \mathrm{C}, 31$ and $98 \%$ and $0 \mathrm{~mm}$ respectively. The infestation of the mango fruit borer was lowest during second week of May when the temperature, relative humidity and rainfall varied from 38.4 and $22.8{ }^{\circ} \mathrm{C}, 51.6$ and $93 \%$ and $27.1 \mathrm{~mm}$ respectively. The fruit borer bored into the fruits both at the young marble stage to more mature ones producing tiny pin head size small circular hole at the point of entry encircled by a dark brown ring. Larvae feeding on the fruit pulp formed network of tunnels to reach the seed, the later instar larvae fed on the seed, filling up the inner content of the fruits with excreta.

\section{Materials and Methods}

Biochemical analysis of the fruit in regard to the phenol content of different stages and parts of mango samples were conducted in Plant Physiology laboratory of Bidhan Chandra Krishi Viswavidyalaya, Mohanpur, Nadia, West Bengal to evaluate the effect of phenol through correlation studies of these chemicals with percentage damage of the fruits by borers. For the experiment in laboratory, mango fruits of different stages were collected from the orchard of Regional Research Station, Gayeshpur, Nadia, West Bengal. The fruits were cut into pieces to separate the pulp and the seed i.e. 
cotyledon part which were dried in a drier for 4 to 7 days and the full dried mango pulp and seed were then ground in the grinder machine thoroughly to get parts of the fruits in dust form and then the analyses were conducted.

Phenols are best described as the aromatic compounds with hydroxyl groups which are widely distributed in the plant kingdom occurring in all parts of the plants. Disease and pest resistance in plants are attributed due to phenol content. Total estimation were carried out with the Folin-Ciocalteau reagent where under alkaline condition phenol reacted with an oxidizing agent phosphomolybdate resulting in the formation of a blue coloured complex, the molybdenum blue which was measured at $650 \mathrm{~nm}$ calorimetrically (Bray and Thorpe, 1954)

The Folin-Ciocalteau reagents comprise of the following: $80 \%$ Ethanol, $20 \% \mathrm{Na}_{2} \mathrm{CO}_{3}$ standard, $100 \mathrm{mg}$ catechol in $100 \mathrm{ml}$ of water diluted 10 times for a working standard. $10 \mathrm{ml}$ of $80 \%$ ethanol was added to the $0.5 \mathrm{~g}$ of sample taken in a test tube. The mixture was centrifuged at $4800 \mathrm{rpm}$ for 20 minutes and later the mixture were kept over a hot air oven to evaporate the ethanol and the dried supernatant were collected. The residue was dissolved in $5 \mathrm{ml}$ distilled water, $0.2 \mathrm{ml}$ pipette out into a test tube and the volume was made up with $3 \mathrm{ml}$ of water. Furthermore to it $0.5 \mathrm{ml}$ of Folin-Ciocalteau reagent was added. 3 minutes later , $20 \mathrm{ml} \mathrm{Na}_{2} \mathrm{CO}_{3}$ solution was added to it mixed thoroughly. The prepared solution was then placed in boiling water for a minute when the materials turn deep blue. The phenol content of the sample was evaluated by the absorbance value of the coloured solution at the $650 \mathrm{~nm}$ wavelength in the spectrophotometer and the absorbance value was compared with the standard phenol curve thus prepared by various catechol concentration.

\section{Results and Discussion}

Results of the biochemical analysis of phenol against mango fruit borer showed the level of its phenol content of pulp and seed at different stages of fruit development of the mango cultivar. It could be noticed that pulp phenol level of the fruits of the mango cultivars ranged from $5.707 \mathrm{mg} \mathrm{kg}^{-1}$ to $23.57 \mathrm{mg} \mathrm{kg}^{-1}$ at marble stage, $2.537 \mathrm{mg} \mathrm{kg}^{-1}$ to $13.493 \mathrm{mg}$ $\mathrm{kg}^{-1}$ at egg stage and from $1.023 \mathrm{mg} \mathrm{kg}^{-1}$ to $11.023 \mathrm{mg} \mathrm{kg}^{-1}$ at maturity stage of the fruit. The variations in the pulp content level of mango cultivars under study were significant at all three stages indicating inherent differences in this respect among the cultivars. The pulp phenol content level of all the cultivars was recorded to be highest at marble stage, gradually decline with the development and found to be lowest at the maturity stage. Whereas the seed phenol level of the cultivars at egg stage ranged from $17.520 \mathrm{mg} \mathrm{kg}^{-1}$ to $25.090 \mathrm{mg} \mathrm{kg}^{-1}$. The variation in seed phenol level of the cultivars was highly significant indicating significant difference among the cultivars in this respect. At maturity stage, the seed phenol level of the cultivars ranged from $23.543 \mathrm{mg} \mathrm{kg}^{-1}$ to $4.983 \mathrm{mg} \mathrm{kg}^{-1}$. The variation in seed phenol level at the fruit maturity of the cultivars was also significant indicating inherent difference among the cultivars in this respect.

From Table 1 it is clear that Himasagar at marble stage had phenol content $21.060 \mathrm{mg} \mathrm{kg}^{-1}$ in the pulp. Infestation of the fruit borer was seen in the Himsagar. Gradually the phenol content declined to $11.023 \mathrm{mg} \mathrm{kg}^{-1}$ in the pulp at maturity when infestation of the pest on the variety grew to reach its

Table 1: Total Phenol content of pulp and seed at different stages of fruit development of the mango cultivars

\begin{tabular}{|c|c|c|c|c|c|}
\hline \multirow[t]{2}{*}{ Variety } & \multirow{2}{*}{$\begin{array}{c}\begin{array}{c}\text { Marble } \\
\text { stage }\end{array} \\
\left(\mathrm{mg} \mathrm{kg}^{-1}\right)\end{array}$} & \multicolumn{2}{|c|}{$\begin{array}{l}\text { Egg stage (mg } \\
\left.\qquad \mathrm{kg}^{-1}\right)\end{array}$} & \multicolumn{2}{|c|}{ Maturity stage } \\
\hline & & Pulp & Seed & Pulp & Seed \\
\hline Neelgoa & 17.721 & 10.892 & 10.598 & 4.985 & 4.983 \\
\hline Neelshan & 12.543 & 6.040 & 20.077 & 2.550 & 18.547 \\
\hline $\begin{array}{l}\text { Prabha } \\
\text { Shankar }\end{array}$ & 13.473 & 3.517 & 25.070 & 1.033 & 13.537 \\
\hline Ratna & 7.067 & 3.567 & 25.060 & 0 & 0 \\
\hline Mallika & 12.553 & 3.567 & 25.090 & 1.060 & 17.533 \\
\hline Amrapali & 18.550 & 2.543 & 25.047 & 1.040 & 23.543 \\
\hline Kesar & 7.557 & 3.530 & 21.060 & 1.057 & 17.520 \\
\hline Zardallu & 10.113 & 5.067 & 20.060 & 2.573 & 17.557 \\
\hline Fazli & 9.110 & 3.567 & 25.090 & 1.060 & 17.533 \\
\hline Bangalora & 10.093 & 5.063 & 25.037 & 1.023 & 23.520 \\
\hline Langra & 23.570 & 12.527 & 17.520 & 7.487 & 15.033 \\
\hline $\begin{array}{l}\text { Arka An- } \\
\text { mol }\end{array}$ & 22.557 & 3.520 & 25.063 & 1.537 & 20.053 \\
\hline Neeluddin & 5.707 & 2.537 & 23.533 & 1.557 & 22.537 \\
\hline Himsagar & 21.060 & 13.493 & 22.507 & 11.023 & 18.523 \\
\hline
\end{tabular}

highest. From Table 2 Himsagar showed mean percentage damaged fruits by the borer of $2.59 \%$ and $2.415 \%$ in 2009 and 2010 respectively. Prabha shankar showed first attack along with Himsagar when phenol content in the pulp at marble stage was $13.473 \mathrm{mg} \mathrm{kg}^{-1}$, thereafter the infestation grew up at maturity when the pulp phenol content declined to 1.033 $\mathrm{mg} \mathrm{kg}^{-1}$. Arka Anmol showed uniformly high level of phenol content from marble to maturity stage and thus showed tolerance to the pest.

It is revealed from Table 3 that the correlation study of the fruit borer infestation with phenol content of pulp and seed at different stages of the fruit development showed infestation strongly associated with the pulp phenol level of fruit maturity $(r=0.78)$ and egg stage $(r=0.73)$ where as it did not have any remarkable association with pulp phenol level at marble stage $(r=0.44)$. However, the correlation study of the borer infestation with phenol level revealed that seed phenol level neither at egg stage nor at maturity stage were associated with the fruit borer infestation. 
Table 2: Varietal preference of mango fruit borer in terms of percent damaged fruits in 2009 \& 2010

\begin{tabular}{lccc}
\hline Variety & $\begin{array}{c}\text { Mean percent dam- } \\
\text { aged fruits by the } \\
\text { borer }\end{array}$ & $\begin{array}{l}\text { Mean percent } \\
\text { damage by borer } \\
\text { in two years }\end{array}$ \\
\cline { 2 - 3 } Neelgoa & 2009 & 2010 & \\
Neelshan & 0.38 & 0.43 & 0.405 \\
Prabha Shankar & 0.29 & 0.495 & 0.392 \\
Ratna & 0.51 & 1.165 & 0.837 \\
Mallika & 0.37 & 0 & 0.185 \\
Amrapali & 0.45 & 0.165 & 0.307 \\
Kesar & 1.51 & 0.25 & 0.880 \\
Zardallu & 1.93 & 0.165 & 1.047 \\
Fazli & 0.35 & 0.33 & 0.340 \\
Bangalora & 0.83 & 0 & 0.415 \\
Langra & 0.38 & 0.332 & 0.356 \\
Arka Anmol & 0.76 & 0.495 & 0.627 \\
Neeluddin & 0.71 & 0 & 0.355 \\
Himsagar & 0 & 0.665 & 0.332 \\
\hline
\end{tabular}

Table 3: Correlation values of fruit borer infestation with phenol content at different stages of fruit development

\begin{tabular}{llc}
\hline Phenol content $\left(\mathrm{mg} \mathrm{kg}^{-1}\right)$ & & Correlation values $(\mathrm{r})$ \\
\hline Marble stage & Pulp & 0.44 \\
\hline Egg stage & Pulp & 0.73 \\
& Seed & -0.36 \\
Maturity Stage & Pulp & 0.78 \\
& Seed & -0.42 \\
\hline
\end{tabular}

\section{Conclusion}

The result of the present experiment was at variance with such previous information. The most interesting part of the findings of the present experiment was that the preference of the borer that reside within the seeds and feed on its cotyledon had no bearing with seed phenol level. Whereas its infestation appeared to have strong and positive association with the pulp phenol level of the fruit at egg and maturity stage.

\section{References}

Anonymous. Ministry of Food Processing Industries (MFPI), Govt, of India and FICCl, 2005.

Anonymous. Surveillance of different mango pests and their natural enemies during 2003-2004 and 2004-2005. In: Ann, Report All India Coordinated Research Project on Sub Tropical Fruits, B.C.K.V. Mohanpur centre, 2007.

Butani, D.K., Mango pest problem. Pub: Periodical Expert Book Agency, New Delhi, 1993, 415.

Bray, H.G., Thorpe, W.V., 1954. Analysis of phenolic compounds of interest in metabolism. Methods of Biochemical Analysis, 1954 ;52: pp. 1-27.

Golez, H.G., Bionomics and control of mango seed borer Noorda albizonalis Hampson (Pyralidae: Lepidoptera). Acta Horticulture 1991; 291: pp. 418-424.

Jha, S., Sarkar, A., Mango in Malda, Bidhan Chandra Krishi Viswavidyalaya, Mohanpur, Nadia, W.B., 1991, pp.13.

Mohyuddin, A.I., Mahmood, R., Integrated control of mango pests in Pakistan. Acta Horticulturae 1993; 341:pp.467483.

Sahoo, A.K., Das, B.K., Incidence and biological observations of mango fruit borer, Deanolis albizonalis Hampson (Pyralidae: Lepidoptera) in West Bengal. Environmental and Ecology 2004; 22(Spl,2):pp.180-183.

Sahoo, S.K., Jha, S. (2009). Bioecology of Mango Fruit borer, Autocharis (=Noorda) albizonalis Hampson (Pyralidae, Lepidoptera)-A Recent Threat to Mango Growers in West Bengal, India. (ed,: S.A.Oosthuyse, Proc.VIII Int. Mango Symposium Acta Hort.820,ISHS 2009) Acta Horticulture, 820:pp.1345-1425.

Verghese, A., Nagaraju, D.K., Jayanthi, P.D.K., Madhura, H.S., Association of mango stone weevil, Sternochetus mangiferae (Fabricius) (Coleoptera: Curculionidae) with fruit drop in mango. Crop Protection 2005a; 24:pp.479-481.

Zaheruddeen, S.M., Sujatha, A., Record of Deanolis albizonalis (Hampson) (Pyralidae: Odontinae) as mango fruit borer inAndhra Pradesh. Journal of the Bombay Natural HistorySociety 1993; 90, 528. 